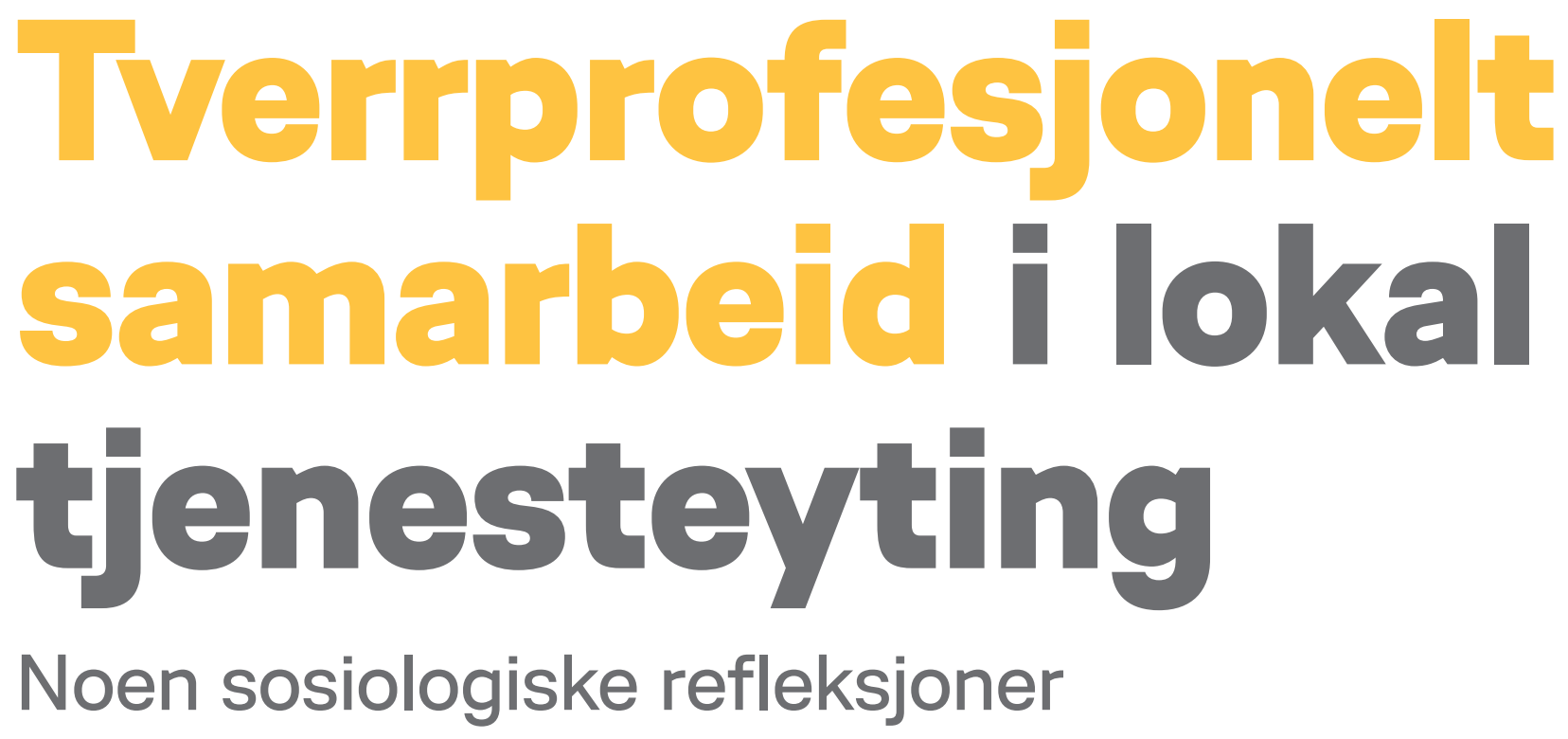

Ann Christin E. Nilsen, ph.d.,

Førsteamanuensis, Universitetet i Agder, Norge

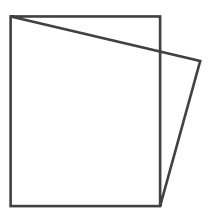

I Norge er proveforelesning en selvstendig del av eksaminasjonen for ph.d.-graden. Hensikten er å prove kandidatens evne til å tilegne seg kunnskaper utover avhandlingens tema, og evnen til å formidle disse i en forelesningssituasjon. Tema for proveforelesningen fastsettes av bedømmelseskomiteen og kunngjøres for ph.d.-kandidaten 10 arbeidsdager for forelesningen. Proveforelesningen skal ha en varighet på 45 minutter, og vurderes umiddelbart etter av bedømmelseskomiteen. Prøveforelesningen må være bestått for disputas kan avholdes. Vanligvis finner disputas sted samme dag eller dagen etter. Denne teksten er basert på Ann Christin E. Nilsens proveforelesning for ph.d.-graden i sosiologi, og har derfor en mer muntlig sjanger enn det som er vanlig for vitenskapelige artikler. Det oppgitte temaet for Nilsens prøveforelesning var: «Drøft muligheter og utfordringer knyttet til tverrprofesjonelt samarbeid i lokal tjenesteyting, i lys av sosiologisk teori». Proveforelesningen fant sted på Universitetet i Agder i Kristiansand den 3. april 2017. 
Tverrprofesjonelt samarbeid i lokal tjenesteyting.

\section{Innledning ${ }^{1}$}

Tverrprofesjonelt samarbeid er et tema som stadig dukker opp når det er snakk om hvordan velferdsforvaltningen kan bedres. Dette gjelder på ulike felt og virksomhetsområder, og ikke minst når det dreier seg om barn. I mitt doktorgradsprosjekt, som dreier seg om tidlig innsats, er det nettopp tverrprofesjonelt samarbeid ovenfor barn som settes $i$ fokus (Nilsen 2017). Selv om Norge rangeres som best i klassen på svært mange områder som vurderes i ulike FN organer, har Norge blitt kritisert av FNs barnekomité nettopp på grunn av svakheter ved samarbeidet knyttet til å yte hjelp og bistand ovenfor barn som strever. ${ }^{2} \AA$ bringe opp dette temaet er derfor viktig i et politisk og forvaltningsmessig henseende. Jeg vil hente de fleste av eksemplene i denne forelesningen fra tverrprofesjonelt samarbeid rundt barn.

Det er ikke tvil om at tverrprofesjonelt samarbeid i lokal tjenesteyting regnes som et gode. Antakelsen som ligger til grunn er at personer med ulik kompetanse har ulike ting å bidra med, som til sammen vil gi en best mulig helhetlig tjeneste til den som er mottaker. Det er med andre ord nettopp heterogeniteten i kunnskap og ressurser som i utgangspunktet anses som en styrke ved tverrprofesjonelt samarbeid. Samtidig er det mange studier som viser at dette ikke er lett. Samarbeid på tvers av profesjoner er vanskelig på grunn av ulikheter i kunnskap og erfaring, på grunn av vansker med rolleavklaring, arbeidsdeling og ressurstilgang, og på grunn av taushetsplikter og ulike forståelser av hva som er samarbeidets mål og mandat (Se f.eks. Jacobsen 2004, Baklien 2009, Grimen 2008).
Tverrprofesjonelt samarbeid er ikke et underforsket felt. Tvert om har mange empiriske studier satt fokus på dette temaet. Det har blitt belyst med utgangspunkt i både sosiale, psykologiske, organisasjonsteoretiske, systemteoretiske og psykodynamiske tilnærminger, for å nevne noen (Reeves 2016:147). Gitt den oppmerksomheten dette temaet har fått både i politikk og forvaltning - og innenfor profesjonsutdanningene - er det overraskende at ikke temaet har vekket større interesse blant sosiologer. Å sette fokus på tverrprofesjonelt samarbeid i et sosiologisk perspektiv er derfor betimelig. Dette åpner også for mer kritiske perspektiver.

I denne forelesningen vil jeg dele noen refleksjoner rundt tverrprofesjonelt samarbeid i lokal tjenesteyting, der jeg trekker veksel på ulike sosiologiske teorier. Jeg vil starte med en liten begrepsavklaring og avgrensing, før jeg gir en nærmere beskrivelse av det argumentet jeg vil fremme.

\section{Begrepsavklaring}

Begrepet tverrprofesjonelt brukes ofte synonymt med tverrfaglig. Likevel er det en liten nyanseforskjell (Willumsen 2009:20-21). Begrepet fag, som for eksempel sykepleiefag eller sosionomfag, omfatter som regel flere disipliner og kan være vanskelig å avgrense. Likevel knytter fag seg ofte til profesjon. Noen profesjoner baserer seg på en fagdisiplin, slik leger bygger på medisin som fagdisiplin, mens andre, såkalte semiprofesjoner, baserer seg på ulike fagdisipliner, slik sosionomer bygger på kunnskap fra for eksempel sosialt arbeid, sosiologi og psykologi. Tverrprofesjonalitet innebærer at det dreier seg om det som skjer mellom profesjonelle. I følge
Andrew Abbot (1988) er profesjoner noen spesielle grupper av individer som benytter en slags abstrakt kunnskap på konkrete oppgaver. Slik jeg bruker begrepet - og her bygger jeg på Abbott - handler det om fagfolks arbeid og aktiviteter, og ikke kun om de organisatoriske instruksene eller betingelsene de jobber under. Når man snakker om tverrprofesjonelt samarbeid så rettes altså fokus mot de profesjonelle og hvordan de samarbeider, og ikke mot samvirket mellom ulike fagdisipliner eller organisasjoner i seg selv. Jeg tar derfor utgangspunkt i profesjonssosiologien når jeg i denne forelesningen skal se på tverrprofesjonelt samarbeid. Jeg kommer til å ha mest fokus på samarbeidet mellom de profesjonelle, og ikke mellom de profesjonelle og borgerne - ikke fordi det ikke er viktig eller relevant - men rett og slett som en avgrensning.

Samarbeid er også et begrep som bør avklares. Flere trekker et skille mellom samordning og samarbeid, der det første - samordning - handler om hvordan organisasjonene tilrettelegger for samhandling ved å lage instrukser, rutiner, arenaer osv., mens det siste - samarbeid - handler om det som faktisk foregår mellom folk som skal samarbeide: hvordan de kommuniserer, handler og forstår sitt mandat osv. (Willumsen 2009, Zahl og Sagatun 2003). Sosiologiske teorier kan brukes til å belyse begge deler, men når jeg her snakker om samarbeid er det først og fremst møtet mellom folk jeg ser for meg, og ikke organisasjonsstrukturene.

Det siste begrepet som trenger avklaring er lokal tjenesteyting. Dette forstår jeg som de profesjonelles handlinger i lokale velferdstjenester, dvs. i tjenester der de 
Tema: Professioner og tværprofessionalitet

profesjonelle er i direkte kontakt med borgerne i deres nærmiljø eller kommune. Borgernes første møte med lokale velferdstjenester er som regel i førstelinjen, dvs. i skole, barnehage, NAV ${ }^{3}$, helsestasjon e.l. Men jeg omfatter også andrelinjetjenester i dette begrepet, som barnevern, $\mathrm{PPT}^{4}$ osv., siden et tverrprofesjonelt samarbeid som regel innebærer en viss samhandling på tvers av tjenester både i første og andrelinjen.

Det samarbeidet jeg skal drøfte er altså et samarbeid mellom profesjonelle i ulike velferdstjenester. Det dreier seg om dem som den amerikanske sosiologen Michael Lipsky omtaler som bakkebyråkrater, eller street-level bureaucrats (Lipsky 1980). Deres rolle er å omsette politiske føringer til praktisk handling, å være forvaltningens ansikt utad - eller med Lipsky's egne ord: «to represent government to the people». De valg bakkebyråkratene tar, de vurderingene de gjør og de virkemidlene de benytter blir i praksis den politikken borgerne møter.

Med denne begrepsavklaringen i bakhodet vil jeg i denne forelesningen drøfte utfordringer og muligheter knyttet til tverrprofesjonelt samarbeid i lys av sosiologiske perspektiver og teorier. Man kan kanskje spørre seg hva sosiologien har å tilby studiet av tverrprofesjonelt samarbeid? Et kapittel skrevet av Scott Reeves (2016) i en bok som er redigert av Elisabeth Willumsen og Atle Ødegård, minnet meg på et begrep jeg ble kjent med da jeg studerte sosiologi grunnfag: den sosiologiske fantasi. Dette begrepet ble introdusert av C. Wright Mills i 1959, og viser til sosiologiens evne til å trekke sammenkoplinger mellom individ og samfunn. Den sosiologiske måten å tenke på handler om en bevisstgjøring omkring sammenhenger mellom personlige erfaringer og samfunnsforhold, og mellom empiri og teori. Med andre ord, hvordan kan individuelle handlinger forstås i lys av vår samfunnsskapte virkelighet? Denne innsikten, eller dette oppdraget, gjør at sosiologiske analyser vil handle om hvordan trender, endringer og samfunnsstrukturer virker inn på individers handlinger.

Argumentet i denne forelesningen vil bygge på tre poeng som står sentralt hos den amerikanske profesjonssosiologen Andrew Abbott, som har skrevet hjørnesteinsverket The system of Professions, utgitt i 1988. Abbott regnes i sosiologisammenheng inn under perspektivet som kalles symbolsk interaksjonisme. Han var opptatt av å forstå samspill mellom profesjoner i et historisk og komparativt perspektiv. Det første poenget til Abbott er at for å forstå hvordan profesjoner virker og endres må man studere folks faktiske arbeid og aktiviteter, og ikke strukturer eller organisasjonskultur som abstrakte fenomener. For det andre kan ikke profesjoner studeres uavhengig av hverandre. Kampen for profesjonell jurisdiksjon, eller eksklusiv kontroll over faglige ekspertise, er helt sentral for profesjonenes væren og virke, og innebærer forhandlinger og konkurranse mellom profesjoner. Og sist, men ikke minst, hevder Abbott at profesjoner må studeres i lys av sin historiske kontekst, som sosiale konstruksjoner. Det ligger implisitt i disse poengene at studiet av profesjoner - og ikke minst samhandlingen mellom profesjoner - bør handle om forhandlinger, i spennet mellom makt og tillit.
La meg allerede nå avsløre det argumentet jeg skal fremme i denne forelesningen - som altså er inspirert av Abbott. Det går som følger: For å forstå tverrprofesjonelt samarbeid i lokal tjenesteytelse må vi først se på hva som kjennetegner profesjoner og de betingelsene de profesjonelle har for sitt arbeid. Noe av det som kjennetegner vår samtid er en mistillit til profesjonene (Halvorsen 2007), som blant annet kommer til uttrykk ved at profesjonelles vurderinger suppleres med, eller erstattes av, evidensbaserte beslutningshjelpemidler. Gitt at tverrprofesjonelt samarbeid handler om en form for forhandlinger, må disse beslutningshjelpemidlene integreres $\mathrm{i}$ analysen av hvordan disse forhandlingene skjer. Jeg avslutter argumentet med å sette fokus på hvordan evidenskravet, paradoksalt nok, bidrar til en homogenisering av forståelser, som man kan hevde svekker mangfoldet i perspektiver og forståelser som et tverrprofesjonelt samarbeid i utgangspunktet er ment å fremme.

La meg starte å bygge opp dette argumentet med et historisk tilbakeblikk på profesjonssosiologien der profesjonenes rolle settes i fokus. Jeg vil legge frem noen av de innsiktene som er utviklet gjennom profesjonssosiologien.

\section{Den profesjonssosiologiske arven}

Talcott Parsons, som hadde sitt mest aktive virke på 50 og 60 tallet, regnes ofte som profesjonsteoriens grunnlegger. I følge Parsons, som innenfor sosiologifaget regnes som en strukturfunksjonalist, er det som kjennetegner forskjellen mellom enkle og komplekse samfunn en økende differensiering, som blant annet innebærer spesialisering og arbeidsdeling. Denne differensieringen 
Tverrprofesjonelt samarbeid i lokal tjenesteyting.

\section{Det er ikke tvil om at tverrprofesjonelt samarbeid i lokal tjenesteyting regnes som et gode.}

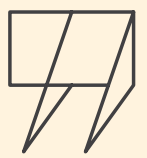

truer ifølge ham den sosiale orden - med mindre den samtidig innebærer en integrering av verdier i samfunnets ulike subsystemer, som familie, skole og arbeidsplass. Slik integrering forutsetter at det skapes konsensus eller enighet om verdier. Og her ligger selve kjernen i hans profesjonsteori. Parsons så på profesjonene som samfunnets verdibærere. De kunnskapsorienterte, profesjonelle verdiene som profesjonene besitter var, ifølge Parsons, et korrektiv til marked og byråkrati. I motsetning til mange andre samfunnsvitere på hans tid, hevdet han at det ikke var kapitalismen og markedet som brakte samfunnet videre, men derimot profesjonene.

Parsons' konsensusorienterte syn på profesjoner blir ofte satt i kontrast med Max Webers mer dystopiske beskrivelse av profesjonenes rolle i samfunnsutviklingen. Weber beskrev allerede på 1920-tallet en idealtypisk byråkratisk modell, som siden har blitt grunnlaget for omtrent all forskning på byråkrati som organisasjonsform. Sentralt i denne modellen er idéen om at embetsverket er inndelt etter kompetanseområder, som krever teoretisk skolering - i likhet med det moderne profesjonssystemet. Systemet er basert på en form for hierarkisk arbeidsdeling, der beslutninger fattes på bakgrunn av abstrakte og generaliserte regler og rutiner, og ikke på vurderinger fra sak til sak. Byråkratiet sikrer på den måten rettferdighet og større likhet mellom velferdstjenestene på tvers av lokasjon. Weber advarte likevel om at byråkratiseringen innebærer en avfortryllelse av verden i sin insistering på aktører som formålsrasjonelle, opptatt av effektivitet og måloppnåelse. Denne rasjonaliseringen hevdet han ville føre til at folk mister troen på fundamentale felles verdier. Handlinger kan med andre ord ikke lenger legitimeres ut fra verdier, men må legitimeres på måter som svarer til en formålsrasjonalitet. Det er dette han omtaler som «rasjonalitetens jernbur». De profesjonelles handlingsrom begrenses, med andre ord, av byråkratiseringen, skal vi tro Weber.
I boka The Rise of Professionalism, fra 1977, hevder imidlertid Magali Sarfatti Larson at det å tegne opp en kontrast mellom Parsons og Weber er et feilspor. For det første fordi de begge er opptatt av betydningen av konsensus om verdier. Og for det andre fordi moderne profesjoner ikke er antitesen til byråkrati, men derimot helt avhengig av byråkrati.

For vårt vedkommende er relevansen av disse tidlige profesjonsteoretikerne knyttet til forståelsen av profesjoner som verdibærere og helt sentrale $\mathrm{i}$ samfunnsbyggingen, og de utfordringene som oppstår i møtet mellom profesjoner og byråkrati. Dette kommer jeg tilbake til.

Hvordan står det så til med profesjonssosiologien her til lands? Sentrale personer i utviklingen av den norske profesjonsteorien er blant andre Vilhelm Aubert, Ulf Torgersen, Knut Dahl Jacobsen og Vibeke Erichsen. ${ }^{5}$ Den norske profesjonsforskningen kan sies å ha utviklet seg $i$ to retninger; en som studerer profesjoner og profesjons- 


\section{For å forstå tverrprofesjonelt samarbeid i lokal tjenesteytelse må vi først se på hva som kjennetegner profesjoner og de betingelsene de profesjonelle har for sitt arbeid.}

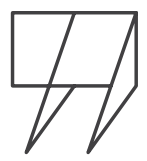

utøvelse «utenfra», som miljøet ved senter for profesjonsstudier ved Høgskolen i Oslo og Akershus, og en som studerer dem «innenfra» med utgangspunkt i praksisnære problemstillinger. Denne siste retningen utføres i all hovedsak av folk som selv har en profesjonsbakgrunn, som på vårt eget institutt her på universitetet.6 Det er særlig denne retningen som har satt dagsorden de siste årene, noe som blant annet kommer til uttrykk i ulike utlysninger både fra forskningsrådet og $\mathrm{i}$ velferdsutdanningene (Støkken 2013). Mitt argument er likevel knyttet til den første retningen.

Rune Slagstad påpeker i boka Profesjonshistorier (2014), blant annet at den norske profesjonssosiologien skilte seg fra den amerikanske tradisjonen ved at den var orientert mot forholdet mellom stat og profesjon, og ikke mellom marked og profesjon. I nordiske land er vår tillit til profesjonene tradisjonelt sett nedfelt i statlige styringsinstrukser, og ikke i en markedslogikk. Makten til profesjonene henger sammen med den tilliten de får fra sine omgivelser, og sånn sett kan man kanskje si at staten i Norge er en garantist for profesjonenes makt. Uten tillit fra stat og borgere, vil denne makten smuldre opp.

Tor Halvorsen (2007) hevder at profesjoner nettopp karakteriseres av denne relasjonen mellom makt og tillit. Tillit er en vesentlig forutsetning for opprettholdelsen av den sosiale orden. I følge Julia Evetts (2003) forstås profesjonalitet innenfor denne retningen som et normativt verdisystem. Mens studiet av profesjonenes fremvekst, i arven etter Parsons, i stor grad handlet nettopp om tillit og konsensus, vokste det blant samfunnsviterne på 70-tallet frem en frykt for den makten som profesjonene besitter. «Stol aldri på en ekspert» var et råd som ofte ble trukket frem, «de vet likevel ikke hva de gjør eller hvorfor». Maktperspektivet, som blant annet knyttes til Bourdieu og hans begrep om symbolsk makt, satt fokus på hvordan tilliten til profesjonene tilslører maktrelasjoner og skaper en form for falsk bevissthet omkring hva profesjonene er og gjør. Kunnskap er koplet til makt og interesser, ble det hevdet, og arbeidsde- lingen mellom profesjonene dreier seg derfor i stor grad om en kamp om definisjonsmakt. Dette er et perspektiv som blant annet har blitt videreført i arbeidene til Michel Foucault. Det er særlig den makt som ligger i diskursene han har vært opptatt av, og hvordan diskursene nedfeller seg i måten vi forholder oss til ulike fenomener $i$ samfunnet på. Hans begrep om governmentality, som kan oversettes til styringsmentalitet, handler i korte trekk om hvordan politiske og sosiale målsetninger nås gjennom styring av befolkningens holdninger, handlinger, verdsettinger osv. De profesjonelle spiller en viktig rolle som formidlere av statens styringsmål til befolkningen. Julia Evetts (ibid.) beskriver følgelig dette synet på profesjonalitet som ideologisk.

Til tross for at maktperspektivet kom inn, og fikk en sentral plass ikke bare i profesjonssosiologien, men i hele sosiologifaget som sådan, står fremdeles konsensusperspektivet - med utgangpunkt i tillitsbegrepet - sterkt i profesjonsteorien. I et moderne, differensiert samfunn så innebærer profesjonstillit på 
Tverrprofesjonelt samarbeid i lokal tjenesteyting.

individnivå at man gir sin tillit til fremmede, som representerer ulike profesjoner. Det dreier seg med andre ord om en tillit til profesjonssystemet, og ikke til enkeltpersoner.

\section{Den nyliberale vendingen}

Det er i spenningen mellom makt og tillit vi finner kimen til den såkalte nyliberale vendingen som kom på 80 -tallet. Denne vendingen knyttes ofte til økt markedsstyring, og ifølge Halvorsen kjennetegnes den av en økt mistillit til profesjonene. Begreper som new public management, accountability og evidens kom inn i samfunnsdebatten, og fikk betydning for profesjonenes virke. Hva handler disse begrepene om? Jo, new public management, som jeg vil referere til som NPM, betegner en styringslogikk der effektivitet og måloppnåelse settes $\mathrm{i}$ sentrum. Et grunnprinsipp i NPM er at mer markedsorientering innenfor offentlig sektor vil lede til et mer kostnadseffektivt tilbud av offentlige goder. Dette krever klare styringsinstrukser. Instrukser, regler og rutiner fastsettes i ulike politiske styringsorganer, som departement, kommunestyrer osv., og pålegger bakkebyråkratene å handle på bestemte måter. Det dreier seg om det bl.a. Bruno Latour omtaler som «action at a distance», eller styring på armlengdes avstand.

Men hvordan kan man vite at bakkebyråkratene handler i tråd med styringsinstruksene? Det er her begrepet accountability kommer inn, som vi på norsk kanskje kan oversette til ansvarliggjøring, eller det å gi begrunnelser for sine handlinger. Det ligger en moralsk konnotasjon i dette begrepet. Likevel brukes det mest som en teknisk styringsbetegnelse, med røtter i finansverden, der det dreier seg om å presentere pålitelige data, fremstillinger og resultater - altså å gjøre opp regnskap med. Å være accountable handler derfor om å kunne dokumentere at du har handlet på måter som er i tråd med styringsinstruksene.

Hvordan kan man så vite at styringsinstruksene er til å stole på? Jo, ved hjelp av evidens. Evidens dreier seg om bevis. Begrepet evidens brukes om kunnskap som er etterrettelig og systematisk fremskaffet, altså kunnskap som bygger på forskning. At tiltak er evidensbaserte betyr at de er utviklet på grunnlag av forskning. Abbott påpeker imidlertid at koplingen mellom ulike tiltak og akademisk kunnskap ofte er mer symbolsk enn praktisk. Begrepet sier heller ikke noe om hva slags kunnskap som gjøres relevant, og tilslører derfor of te at forskningsbasert kunnskap kan være omstridt og gjenstand for kritikk - noe tilhengerne av maktperspektivet har gjort oss oppmerksom på.

Den praktiske konsekvens av disse trendene, for bakkebyråkratenes vedkommende, er at de må svare for sine handlinger. Med andre ord: Deres vurderinger, valg og handlinger må dokumenteres for å kunne legitimeres. Julia Evetts (2003) påpeker, ved å vise til Foucault, at det nye kontrollregimet innebærer en utstrakt disiplinering av de profesjonelle. Handlingene deres kan potensielt sett alltid overvåkes, og de profesjonelle må handle deretter. Halvorsens poeng om at den nyliberale vendingen innebærer en mistillit til profesjonene handler med andre ord om at de profesjonelles beslutninger må støttes av evidens i form av ulike kunnskapsbaserte beslutningshjelpe- midler, og at beslutningene må dokumenteres. Konsensusen som springer ut fra en kollektiv profesjonsidentitet, og som både Parsons og Weber var opptatt av, skapes med andre ord ikke av felles verdier, men av felles beslutningssystemer. Dette er også et sentralt poeng hos den amerikanske sosiologen Steven Brint. Han mente at den kollektive profesjonstilhørigheten blant annet springer ut fra idéen om at kunnskapen til de profesjonelle skal tjene samfunnet. Denne identiteten svekkes i dag av at markedets etterspørselslogikk har blitt sterkere (Brint 1994). Kunnskapsbaserte, tekniske løsninger blir en del av et institusjonalisert kunnskapssystem som langt på vei erstatter, eller iallfall reduserer, det profesjonelle skjønnet. Disse systemene har blant annet som formål å fremme en abstrakt rettferdighet der alle mennesker skal behandles likt, jfr. Webers byråkratimodell. Profesjoner og byråkrati blir med andre ord likere, men, som Tor Halvorsen påpeker, på byråkratiets premisser.

Som en parentes er det verdt å nevne at mange av disse evidensbaserte systemene er kommersialiserte - dvs. at noen har utviklet dem bl.a. med sikte på å tjene penger. Hvorvidt det fremdeles er staten som er garantist for profesjonenes makt, og ikke markedet, kan man med andre ord spørre seg om. Men den ballen lar jeg ligge i denne omgang.

La meg vie tid til et lite eksempel. I min avhandling har jeg intervjuet folk som jobber i barnehager om deres bekymringer for barn. Alle forteller at de har vært bekymret, eller hatt en vond magefølelse for enkelte barn. Denne vonde magefølelsen legitimerer imidlertid ikke at det settes inn noen tiltak. Først må mage- 


\section{Verdiene har ikke forsvunnet fra profesjons- utøvelsen, som legitimeringsgrunnlag, selv om det tilsynelatende er formålsrasjonaliteten som styrer i den nyliberale tidsånden.}

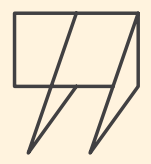

følelsen begrunnes og dokumenteres. Til det kan de bruke ulike evidensbaserte beslutningshjelpemidler, som TRAS eller ALLE MED kartlegging7, eller de kan vurdere barnets omsorgssituasjon i lys av Kvellos liste over risiko- og beskyttelsesfaktorer (Kvello 2011:168-170). Først når observasjonene deres av barnet er dokumentert, og foreldrene har samtykket, kan tiltak settes inn. De som setter inn tiltak kommer som regel fra etater utenfor barnehagen, som PPT, helsesektoren eller barnevernet. Ofte har de ikke møtt barnet - men de har fått barnet beskrevet ved hjelp av ulike kartleggingsskjema, rapporter og vurderinger. Det er på bakgrunn av denne tekstlige fremstillingen av barnet de må ta sine beslutninger.

Vi kan la denne korte beskrivelsen tjene som eksempel på en beslutningsprosess som involverer ulike fagfolk. Abbott (1988) hevder at beslutningsprosesser kjennetegnes av tre faser: først diagnostisering - med andre ord: «hvordan omsette en vond magefølelse til en legitim bekymring?», deretter vurdering eller analyse - «hvordan kan bekymringen forstås?», og til slutt behandling eller tiltak - «hva kan vi gjøre med bekymringen?». Når man skal studere tverrprofesjonelt samarbeid er det hensiktsmessig å tenke på dette som en prosess. Abbott påpeker at det særlig er i den andre fasen, som handler om vurdering og analyse, at profesjonelle må samarbeide, eller forhandle om hvordan problemet skal forstås og håndteres, og det er nettopp i denne fasen man særlig gjør bruk av beslutningsredskaper.

På bakgrunn av eksempelet og beskrivelsen av den nyliberale vendingen kan man kanskje stille spørsmål ved om de profesjonelle har blitt redusert til byråkrater eller teknokrater, som har som sin viktigste rolle å følge styringsinstruksene. Jeg mener at det er grunn til større optimisme enn det. Fremdeles kan man si, slik både Abbott (1988) og Friedson (2001) påpeker, at det faglige skjønnet er selve kjernen i det profesjonelle arbeidet - selv om det riktignok begrenses av styringsinstrukser og restriksjoner. Noen vil hevde at en slik begrensning er helt nødvendig. For eksempel viser Geir Kirkebøen (2013) at verken utdanning eller intelligens gir grunnlag for å stole på fagfolks skjønn. Skjønnsutøvelse sikrer fleksibilitet og individuell tilpasning, men innebærer samtidig en risiko for misbruk og vilkårlighet. Det er nettopp av den grunn begreper som accountability ansvarliggjøring - gir resonans. Anders Molander (2013) skiller mellom to former for ansvarliggjøringsmekanismer: strukturelle mekanismer, som har til hensikt å begrense rommet for skjønnsutøvelse, og epistemiske mekanismer, som har til hensikt å bedre resonneringen som ligger til grunn for skjønnsutøvelsen. Denne resonneringen kan støttes av beslutningsredskaper, som de jeg har vært inne på tidligere, men også av drøftinger i en tverrprofesjonell gruppe. Tverrprofesjonelt samarbeid i bakkebyråkratiet kan, med andre ord, forstås som en form for epistemisk ansvarliggjøring, der hensikten er å bedre begrunnelsene bak profesjonell skjønnsutøvelse.

I denne forbindelsen er det relevant å trekke inn verdier igjen. Verdiene har ikke 
Tverrprofesjonelt samarbeid i lokal tjenesteyting.

forsvunnet fra profesjonsutøvelsen, som legitimeringsgrunnlag, selv om det tilsynelatende er formålsrasjonaliteten som styrer i den nyliberale tidsånden. Jürgen Habermas' begrep om kommunikativ rasjonalitet kan være egnet til å belyse akkurat dette. Begrepet bygger på en antakelse om at alle talehandlinger har som formål å oppnå gjensidig forståelse. Dette er mulig, mener Habermas, fordi vår instrumentelle rasjonalitet til syvende og sist beror på en grunnleggende kommunikativ rasjonalitet, som er tuftet på universelle normer. Det er denne formen for rasjonalitet som forhindrer det han kaller «systemverdens kolonisering av livsverden». De profesjonelle er med andre ord ikke bare tekniske eksperter, men aktører som skaper mening gjennom utveksling av kunnskap, fortolkning og verdier. Det dreier seg med andre ord om refleksivitet.

Den nyliberale vendingen skaper visse utfordringer for det tverrprofesjonelle samarbeidet - eller i det minste legger den visse betingelser for samarbeidet, som det er grunn til å være oppmerksom på. Mulighetsrommet ligger nettopp i refleksiviteten over disse betingelsene. Og det er dette jeg vil vende fokus mot videre.

\section{Tverrprofesjonelt samarbeid som forhandling}

La meg starte med å minne om Abbotts poeng om at profesjoner ikke kan studeres uavhengig av hverandre. Profesjonenes væren og virke handler langt på vei om kampen om den profesjonelle jurisdiksjon. Hva betyr det? Jo, profesjonell jurisdiksjon handler om institusjonalisering av ekspertise. For profesjoners overlevelse er det viktig å sikre sin egenart. Dette skjer både gjennom en monopolisering av kunnskap - som gjør at andre ikke uten videre kan innta profesjonens rolle, og gjennom å sikre profesjonens autonomi og definisjonsmakt.

La oss ta et eksempel. Vi kan se for oss et barn som har en sen språkutvikling. Hvordan kan dette barnet hjelpes? Pedagogene som jobber i barnehagen har gjennom sin utdanning og praktiske erfaring tilegnet seg mye kunnskap om hvordan de kan sette sammen lekegrupper, ha språkleker, lese bøker osv. med sikte på å bedre barns språkutvikling. Fra en spesialpedagogs perspektiv kan likevel disse aktivitetene betraktes som tilfeldige eller uegnet. For spesialpedagogen vil det kanskje være viktig å finne en slags teoretisk forståelse, eller diagnose, av barnets problem, og å sette inn mer tilpassede tiltak. For spesialpedagogen vil det derfor være viktig å få frem, ovenfor pedagogene, at hun har kunnskap som skiller seg fra den kunnskapen pedagogene har, og som andre pedagoger eller profesjoner ikke uten videre kan erstatte.

Harald Knudsen (2004) bruker begrepet domene om den institusjonaliserte faglige ekspertisen, eller jurisdiksjonen, og hevder at profesjonelle med delvis overlappende domener har bedre betingelser for å samarbeide enn profesjonelle uten overlapp eller med fullstendig overlappende domener. Sånn sett kan man tenke seg at samarbeidet mellom pedagoger og spesialpedagoger $\mathrm{i}$ barnehagen bør ha ganske gode kår. Hva så om en fysioterapeut kom inn i dette samarbeidet? Kanskje hun ville sett svakheter ved barnets rygg- og nakkemuskulatur som gjorde at barnets talerør lå i klem? Eller en barnevernspedagog, kanskje hun ville rettet oppmerksomheten mot barnets omsorgssituasjon, og vært opptatt av tilknytningen mellom barnet og hans foreldre? Mens eksempelet med pedagoger og spesialpedagoger handler om forhandlinger knyttet til hvordan problemet skal løses, er forhandlingene mellom pedagogene og fysioterapeuten eller barnevernspedagogen snarere knyttet til hvordan problemet skal forstås. Hva slags oppslutning man får for sine anbefaling avhenger, til dels, av de andre aktørenes tillit til den profesjonelle jurisdiksjonen. Tilliten til en leges forståelse, som av mange trekkes frem som en modellprofesjon, vil ofte være større enn tilliten til profesjoner som baserer seg på et mer sammensatt faggrunnlag.

I et tverrprofesjonelt samarbeid kan man i lys av perspektivet til Abbott derfor si at det vil være viktig å forhandle frem en enighet eller felles forståelse knyttet til avgrensing av kunnskapsområder og mandat. Forhandlingsbegrepet favner bredt, og omfatter både tillit og maktutøvelse - eller konsensus og konflikt - som er en vanlig sosiologisk dikotomi, selv om hovedvekten nok ofte oppfattes å være på det første. Et relevant perspektiv å trekke opp er det Anselm Strauss, som innenfor sosiologifaget knyttes til symbolsk interaksjonisme, betegner som a negotiated order, altså en fremforhandlet orden.

Den sentrale idéen i dette perspektivet er nettopp poenget om at den sosiale orden er et produkt av forhandlinger mellom ulike aktører. Strauss hevdet at alle organisasjoner er avhengig av forhandlinger, enten det dreier seg om hestehandel, kompromiss eller megling, 
Tema: Professioner og tværprofessionalitet

og at det er disse forhandlingene som bidrar til å opprettholde organisasjonens form, regler og systemer - altså den sosiale orden. Disse forhandlingene skjer imidlertid i tråd med, eller i dialog med, de strukturelle og kulturelle forholdene ved organisasjonen, og er derfor ikke tilfeldige. Struktur og kultur i organisasjoner kan handle om instrukser og betingelser, men også om normer, taus kunnskap og «alt det vi vet uten å vite at vi vet det». Å studere forhandlinger i lys av hele denne konteksten er derfor viktig, ifølge Strauss. Det er likevel et sentralt poeng hos ham at det er forhandlingene på mikronivå, og ikke rammene på makronivå, som er det mest sentrale for organisasjonens liv. Forhandlinger er heller ikke noe som avsluttes, men foregår i en vedvarende prosess der den sosiale orden stadig endres og utvikler seg. Perspektivet om den fremforhandlede orden får derfor frem hvordan sosial orden skapes og endres refleksivt, dialektisk og over tid.

Hvem er så aktørene i disse forhandlingene? Først og fremst folk - de profesjonelle som er en del av organisasjonen. Det er de som utveksler synspunkt, erfaringer og kunnskap. Men jeg vil også ta til orde for at en interaksjonistisk analyse av tverrprofesjonelt samarbeid bør inkludere styringsredskaper - ikke bare som organisatoriske betingelser eller strukturelle rammer, men også som aktører. Med styringsredskaper tenker jeg da på evidensbaserte modeller og redskaper, som organisasjonene er forpliktet til - eller iallfall rådet til - å bruke, som f.eks. TRAS i barnehager.

Her tilfører innsikter fra aktør-nettverksteori, slik den er utformet av Bruno Latour med flere, noen viktige poenger (se f.eks. Latour 2005). Et sentralt poeng hos Latour er at det han kaller ikkemenneskelige aktører, altså objekter, tekster e.l., har en egen agency, eller handlingspotensial. Det vil si at de har en betydning for et handlingsforløp. Noen banale eksempler er at fartsdumper får folk til å bremse, og at gjerder - eller murer - får folk til å snu. Disse objektene har ikke agency i seg selv, men forutsetter menneskelig tilstedeværelse. Likevel har de en betydning for det som skjer videre. Uten objektene ville handlingsforløpet vært annerledes. Ikke-menneskelige aktører bør derfor innlemmes i en analyse av sosial samhandling, ifølge Latour. Et lignende argument finner vi hos Dorothy Smith, men først og fremst med fokus på hvilken rolle tekster, $i$ bred forstand, har for et handlingsforløp (se f.eks. Smith 2005, Smith og Turner 2014). Et eksempel kan være hvordan et styringsredskap som individuell plan eller individuell opplæringsplan setter premisser for hva samarbeidet mellom profesjonelle skal handle om. Et annet eksempel er hvordan ulike tekstlige representasjoner av folk, som høyde-vekt skalaer for barn eller karakterutskrifter, sirkuleres og får betydning for de avgjørelser og valg som fattes av profesjonelle.

Tekster eller objekter gjør med andre ord noe eller får noe til å skje. Riktignok kan de ikke løsrives fra folk - det er folk som lager og bruker modellene, fyller ut skjemaene og leser manualene - og som tar beslutninger. Poenget er likevel at slike redskaper er en sentral del av beslutningsprosessen og får betydning for de avgjørelsene som treffes.

Men hvordan bidrar så disse styringsredskapene til «a negotiated order» i et tverrprofesjonelt samarbeid? Jo, slike redskaper, som tilsynelatende bygger på teoretisk kunnskap, fungerer som en slags autorisasjon. Riktignok blir mye av den teoretiske kunnskapen oppløst i praksis, slik Abbott påpeker, men redskapene blir likevel brukt til å legitimere bestemte vurderinger og handlinger. Redskapene benyttes av ulike profesjoner, men stadig oftere ser vi at de reiser mellom profesjonene, og brukes på tvers av profesjoner. Med andre ord lever de sitt eget liv, løsrevet fra en bestemt profesjonell forankring. La meg her gjøre oppmerksom på en artikkel av DiMaggio og Powell (1983), der de blant annet beskriver hvordan byråkratiske organisasjoner blir mer og mer like hverandre pga. ensrettingen i kunnskapssyn og evidensbaserte systemer som følger av den nyliberale vendingen. Dette fører til en homogenisering av kunnskap, hevder de - stikk i strid med idéen om at det er heterogeniteten i kompetanse og forståelser på tvers av profesjoner som beriker det tverrprofesjonelle samarbeidet. Et eksempel på kunnskap som har reist på tvers av profesjonsgrenser, og som Agnes Andenæs nylig trakk frem i en forelesning hun holdt her på UiA, er tilknytningsteori. Denne teorien ligger til grunn for mange av forståelsene knyttet til hva som er god omsorg og hva som ikke er det, og kommer til uttrykk i ulike modeller og konsepter, som f.eks. Kvello modellen eller circle of security. Et annet eksempel er stadielæren, som ligger til grunn for mange av de redskapene som brukes når vi skal vurdere om et barn utvikler seg normalt, enten det er i barnehagen, på skolen eller helsestasjonen. Løsrevet fra det verdibaserte profesjonskollektivet lever disse teoribaserte beslutningsredskapene sitt eget liv, og er først og fremst knyttet til styringen som skjer på armlengdes avstand, og som 


\section{Den sentrale idéen i dette perspektivet er nettopp poenget om at den sosiale orden er et produkt av forhandlinger mellom ulike aktører.}

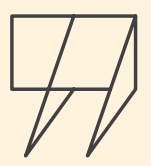

svar på en markedsbasert etterspørselslogikk.

Hvis man, i tråd med Habermas, tenker seg at et byråkratisk samarbeid ikke bare hviler på aktørenes formålsrasjonelle vurderinger, men også på en kommunikativ rasjonalitet, så kan man betrakte styringsredskapene som en form for talehandling. Det «dialogiske» ved denne talehandlingen er likevel begrenset. Tekstene er stabile, de endrer seg ikke. Det er i bruken av de tekstlige redskapene forhandlingene kan oppstå - altså om, når og hvordan de profesjonelle anvender slike redskaper. Til dels vil dette være styrt av styringsinstruksene, men til dels vil det også være et spørsmål om de profesjonelles egne vurderinger, deres faglige skjønn - eller mellom det Julia Evetts (2009) betegner som yrkesprofesjonalitet og organisatorisk profesjonalitet. Refleksiviteten ligger nettopp i de vurderingene de profesjonelle gjør. Som samfunnets verdibærere, for å sitere Parsons, er de profesjonelles vurderinger en forhandling både mellom deres forskjellige profesjonelle etos, og mellom de profesjonelle verdiene og de tekniske styringsinstruksene.

I en artikkel om profesjonelt arbeid $\mathrm{i}$ barnevernstjenesten setter Nordstoga og Støkken (2011) fokus på den skvisen de profesjonelle befinner seg i. Kanskje, undrer de, vil resultatet av det økende styringstrykket føre til at de profesjonelle blir to-språklige, dvs. at de har et formelt språk som tilfredsstiller kravene ovenfra, og et annet, mer uformelt språk, som brukes i det daglige der de små, direkte beslutningene som berører folks hverdagsliv fattes. Dette vil i så fall være en pragmatisk og refleksiv løsning på en klemme som Bourdieu (1999), i boka The Weight of the World, betegner som en umulig oppgave.

\begin{abstract}
Mulighetene og utfordringene knyttet til tverrprofesjonelt samarbeid i lokal tjenesteyting, sett i lys av sosiologisk teori, ligger i den refleksive analysen av spenningene mellom tillit og makt, mellom profesjon og byråkrati, og mellom den verdibaserte profesjonelle identiteten og styringsinstruksene. Sosiologien bidrar til å synliggjøre disse spenningene, og å få frem relevansen av å studere individers handlinger i lys av strømninger i tiden. Sosiologi er en grunnleggende kritisk disiplin. Å stille kritiske spørsmål ved den antatte godheten av tverrprofesjonelt samarbeid bør derfor være et siktemål i en sosiologisk analyse.
\end{abstract}




\section{REFERENCER}

Abbott, A. (1988). The system of professions. Chicago: The University of Chicago Press.

Baklien, B (2009). Skole, barnehage, barneverntjeneste - bilder av "de andre" hindrer samarbeid. Norges Barnevern nr 4, vol 86, s 236-245.

Barneombudet (2009). Supplerende rapport til FNs komité for barns rettigheter. Hentet fra http://barneombudet.no/ wp-content/uploads/2013/09/supplerender-rapport-tilfn_norsk-web.pdf

Bourdieu, P. (1999). An Impossible Mission. I Bourdieu, P. et al.: The Weight of the World. Social Suffering in Contemporary Society. Cambridge: Polity Press.

Brint, S. (1994). In an Age of Experts. The changing role of professionals in politics and public life. Princeton, NJ: Princeton University Press.

DiMaggio, P.J. \& W.W. Powell (1983). The Iron Cage Revisited: Institutional Isomorphism and Collective Rationality in Organizational Fields. American Sociological Review, 48 (2), 147-160.

Evetts, J. (2003). The Sociological Analysis of Professionalism. International Sociology 18 (3): 395-415.

Evetts, J. (2009). New Professionalism and New Public Management: Changes, Continuities and Consequences. Comparative Sociology 8 (2009): 247-266

Friedson, E. (2001). Professionalism. The Third Logic. Chicago, Illinois: University of Chicago Press.

Grimen, H. (2008). Profesjon og tillit. I Molander, A. og L. Terum (red): Profesjonsstudier. (S. 197-215). Oslo: Universitetsforlaget.

Halvorsen, T. (2007). Profesjonar, makt og tillit. I Hjellbrekke, J., O.J. Olsen og R. Sakslind: Arbeid, kunnskap og sosial ulikhet. Bergen: Unipub.

Jacobsen, D.I. (2004). Tverretatlig samarbeid i et organisasjonsteoretisk perspektiv. I Repstad, P (red.): Dugnadsånd og Forsvarsverker. Tverretatlig samarbeid i teori og praksis. 2. utgave. Oslo: Universitetsforlaget.

Kirkebøen, G. (2013). Kan vi stole på fagfolks skjønn? I Molander A. og J-C Smeby (red.): Profesjonsstudier II. (S. 27-43). Oslo: Universitetsforlaget.
Knudsen, H. (2004). Samarbeid på tvers av organisasjonens grenser. I Repstad, P (red.): Dugnadsånd og Forsvarsverker. Tverretatlig samarbeid i teori og praksis. 2. utgave. Oslo: Universitetsforlaget.

Komitéen for barnets rettigheter (2010). Vurdering av rapportene som partene har lagt fram i henhold til konvensjonens artikkel 44. Hentet fra: https://www.regjeringen.no/contentass ets/070c9c0cc01e42fcba35be64ee06b535/bk4-eksaminasjonen---avsluttende-merknader-8-4-10.pdf

Kvello, Ø. (2011). Barn i risiko. Skadelige omsorgssituasjoner. Oslo: Gyldendal Norsk Forlag.

Larson, M. S. (1977). The Rise of Professionalism: A Sociological Analysis. Berkeley: University of California Press.

Latour, B. (2005). Reassembling the Social. An Introduction to Actor-Network-Theory. Oxford: Oxford University Press.

Lipsky, M. (1980). Street-level bureaucracy. Dilemmas of the individual in public services. New York: Russell Sage Publications.

Mills, C. Wright (1959). The Sociological Imagination. Oxford University press

Molander, A. (2013). Profesjonelt skjønn i velferdsstaten: mekanismer for ansvarliggjøring. I Molander A. og J-C Smeby (red.): Profesjonsstudier II (S. 44-54) Oslo: Universitetsforlaget.

Nilsen, A.C.E. (2017). Bekymringsbarn blir til. En institusjonell etnografi av tidlig innsats som styringsrasjonal i barnehagen. Doktorgradsavhandling, Universitetet i Agder.

NOU 2009:22 (2009). Det du gjør, gjør det helt. Bedre samordning av tjenester for utsatte barn og unge. (Flatø-utvalget) Oslo: Barne- og likestillingsdepartementet.

Nordstoga, S. og A.M. Støkken (2011). Professional work in the squeeze. Experiences from a new control regime in residential care for children and youth in Norway. Journal of Comparative Social Work, 6 (2), 1-18.

Reeves, S. (2016). Sosiologisk forståelse av tverrprofesjonell utdanning og praksis. I Willumsen, E. og A. Ødegård: Tverrprofesjonelt samarbeid. Et samfunnsoppdrag. 2. utgave. Oslo: Universitetsforlaget. 
Tverrprofesjonelt samarbeid i lokal tjenesteyting.

Slagstad, R. (2014). Profesjonene i norsk samfunnsforskning. I Slagstad R. og J. Messel: Profesjonshistorier. Oslo: Pax forlag, s $13-43$

Smith D.E. (2005). Institutional Ethnography. A sociology for people. Lanham, Md: AltaMira.

Smith, D.E og Turner, S. (2014). Introduction. In D. Smith \& S. Turner, Incorporating Texts into Institutional Ethnographies (1st ed., pp. 3-14). Toronto: Toronto University Press.
Støkken, A.M. (2013). Profesjonsstudier II redigert av Anders Molander og Jens-Christian Smeby, Universitetsforlaget. Bokanmeldelse for Norsk Statsvitenskapelig Tidsskrift.

Willumsen E. (2009). Tverrprofesjonelt samarbeid i praksis og utdanning. Oslo: Universitetsforlaget.

Zahl, M-A. og S. Sagatun (2003). Det vanskelige samarbeidet. I Zahl, M-A (red.): Sosialt arbeid. Refleksjon og handling. (S. 241-258). Bergen: Fagbokforlaget.

\section{ENDNOTES}

1 Takk til Anne Marie Støkken og Ove Skarpenes som har lest utkast og bidratt med innspill og kommentarer i forberedelsene til forelesningen.

2 Utfordringene knyttet til samordning av tjenester for barn og unge ble særlig satt på dagsorden i NOU 2009:22 (2009) og i Barneombudets supplerende rapport til FNs barnekomité (Barneombudet 2009). FNs barnekomité uttrykker i sin vurdering av 2010 en bekymring for at mangelen på samordning skal føre til at utsatte grupper av barn blir offer for mangler i implementeringen av deres rettigheter (Komiteen for barnets rettigheter 2010).

3 NAV er den norske arbeids- og velferdsforvaltningen, som består av den statlige arbeids- og velferdsetaten og de delene av kommunenes sosialtjenester som inngår i de felles lokale kontorene.

4 PPT står for pedagogisk-psykologisk tjeneste. Dette er en kommunal eller fylkeskommunal rådgivende tjeneste som fungerer som sakkyndig instans i spørsmål om barn, ungdom og voksnes opplæringssituasjon og behov for spesialundervisning.
5 Aubert og Torgersen publiserte i 1960, sammen med Tore Lindbekk og Sonja Pollen, artikkelen «Akademikere i norsk samfunnsstruktur» i Tidsskrift for Samfunnsforskning. Artikkelen anses som en pionér innen profesjonssosiologi, sosial mobilitetsforskning og eliteforskning. Dahl Jacobsen opprettet faget administrasjon og organisasjonsvitenskap på Universitetet i Bergen på 60-tallet, og var, sammen med Tor Halvorsen og Vibeke Erichsen, også sentral i utviklingen av profesjonssosiologien. Hvilket av disse to miljøene som har hatt mest innflytelse på utviklingen av profesjonsforskningsmiljøet ved HiOA er uklart, men alle disse miljøene har til felles at de studerer profesjoner «utenfra».

6 Institutt for sosiologi og sosialt arbeid ved fakultet for Samfunnsvitenskap på Universitetet i Agder.

7 TRAS står for tidlig registrering av språkutvikling. Det er det mest brukte observasjonsredskapet i norske barnehager, og er også brukt i svenske og danske barnehager. ALLE MED er, i likhet med TRAS, et observasjonsredskap som brukes i mange norske barnehager. Formålet favner imidlertid bredere, og redskapet dekker forhold som angår både barnas sosiale utvikling og språkutvikling. 